\title{
中性子回折による残留応力測定技術の確立と中性子産業利用の促進
}

林 眞琴

(総合科学研究機構)

\section{Establishment of Residual Stress Measurement Technique and Promotion of Industrial Application of Neutron to Industry}

Makoto Hayashi

Comprehensive Research Organization for Science and Society

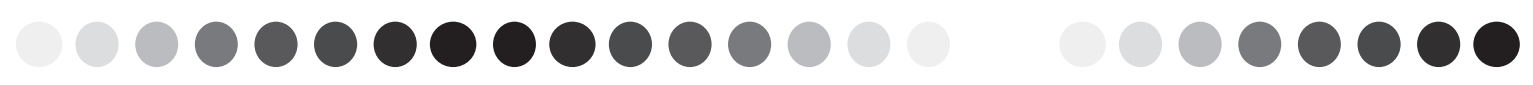

\begin{abstract}
Residual stress measurement technique using neutron diffraction has been developed with supports of Canadian Neutron Beam Center and JAERI (Present JAEA). As Ibaraki Prefecture installed two neutron diffraction apparatuses in J-PARC MLF, I took office as Senior Director. In 2008, I established Industrial Users Society for Neutron Application. Now a number of member is 50 (2 institutes, 48 companies). For the promotion of industrial application, 10 research groups are organized, two type training sessions are held and delivery courses at the companies are held. These activities lead to the allocated proposals for J-PARC MLF occupy about 30\% through from 2008 to 2017. This value is incredibly higher compared with the world's most advanced experimental facilities.

Keywords: Neutron diffraction, Residual stress, Texture, Industrial application
\end{abstract}

\section{1.はじめに}

中性子回折による残留応力測定の研究に取り組 み始めたきっかけは工場からの依頼でした。1990 年に原子カプラントの小口径配管の接続部に用い られているソケット溶接継手において疲労き裂の 貫通により蒸気漏洩が発生しました。溶接金属ル 一ト部の残留応力が高いことが要因であると推定 されましたが，有限要素法の解析に頼るしかない という状況で，検査部門から何とか測定できない かとの相談が持ち込まれました。測定する場所は 小口径配管の内部であるため，X 線回折法やひず みゲージ法は適用できず，侵入深さの大きい中性 子回折法しかないと伝えたところ，測定して欲し いとのことでした．JRR-3 で中性子実験を行って いることは承知していましたが，企業が使える環 境にないということで，海外の施設を利用するこ とにしました。海外施設の技術レベルと測定費用 の見積りを比較調査するため, 米国, カナダ, イ ギリスなど 5 施設を訪問することにしました。

JRR-3 は利用できないとしても, 実験装置や研究 体制がどのようになっているかは把握しておくべ きということで，海外調査の 2 週間前につてを頼 って当時の原子力研究所東海研究所材料研究部の 舩橋達部長を訪問しました。森井幸生氏と皆川宣 明氏に中性子回折による構造物内部の残留応力測 定方法を説明したところ，その場で共同研究をす
ることになりました。また，偶然ですが私たちが 議論している傍に当時室蘭工業大学の博士課程に おられた大沼正人北海道大学教授が居合わせてお られました。海外調査の結果, 当時の AECL の Chalk River Laboratories（現在は Canadian Neutron Beam Centre, NRC) で測定することになりました。

Chalk River Lab.では T. Holden 博士や現在所長 を務めている J. H. Root博士らが非常に懇切丁寧 に対応してくれました。後述する弾性定数の回折 面依存性を明らかにするため，測定費用として支 払った大半のお金を使って，回折装置に載る引張 試験装置を特注で製作してくれ，中性子回折法に よる残留応力測定技術を確立することができまし た。そのうえで, 問題のソケット溶接継手や配管 突合せ溶接継手における残留応力を測定しました。 それらの成果を元に，JRR-3 に日本で最初の中性 子残留応力測定装置（RESA:Residual Stress Analyzer）を東海研究所と共同で設計・製作し, 一般ユーザーの利用に供して来ました。

J-PARC が建設されることになり, 茨城県では産 業利用のために 2 台の中性子実験装置（現在の BL20 材料構造解析装置「iMATERIA」と BL03 生 命物質構造解析装置「iBIX」）を整備することにな りました。私はそれら 2 台の装置の統括する茨城 県企画部技監に 2006 年に就任し, 実験装置の設計 段階から現在の運営体制の確立まで関わりました。 
2 台の実験装置の産業利用を図るために, 茨城 県では 2005 年から茨城県中性子産業利用促進研 究会を組織し, 13 個の個別研究会を設立しました. 私は 2 台の装置の産業利用を促進するためには, 産業界としての活動組織を作るべきと考え，中村 道治日立製作所副社長 (現 JST 顧問)にお願いし, 中性子産業利用推進協議会を発足させました。こ の協議会では中性子の利用促進を図るため 10 個 の研究会を組織し, 産業界のニーズと施設側のシ ーズのマッチングを図る努力を重ねてききした.

2017 年 4 月現在, 研究会の登録メンバーは延べで は1,660 名です。

JRR-3 においては2006年に開始されたトライア ルユース制度の効果があり，順調に産業利用が拡 大していましたが, 残念なことに 3.11 大震災以来 運転を停止しています.J-PARC MLFにおいては 2008 年の供用開始以来, 順調に産業利用採択課題 が増えていましたが，2012 年以降は 40 件程度で やや停滞気味です。なお，茨城県 BL では産業界 の利便性を考慮して 2012 年から運転サイクル毎 に課題を受付ける随時受付け制度を開始し，2016 年からはいつでも課題を受付ける制度に変更しま した．さらには，2014 年から利用者が MLF に来 なくても装置グループが測定してデータと試料を 返送するメールインサービス制度を始めました。

これらの効果があり,「iMATERIA」では約半数の 課題が成果専有での利用となっています.

以下, 受賞に関わる残留応力測定技術の開発と 中性子の産業利用の概要をご紹介致します.

\section{2. 中性子回折による残留応力測定}

中性子回折による構造物の残留応力測定の試み は 1975 年頃から盛んに行われていました[1]. し かしながら,それらは残留ひずみの測定に留まり， 精度良い応力測定とは言えませんでした。それは ひずみから応力に変換するときに必要となる弾性 定数（ヤング率 E，ポアソン比v）の回折面依存性 が考慮されていなかったことにあります.そこで, 応力測定技術を確立するため, まず, 弹性定数の 回折面依存性を明らかにするとともに, 弾性定数

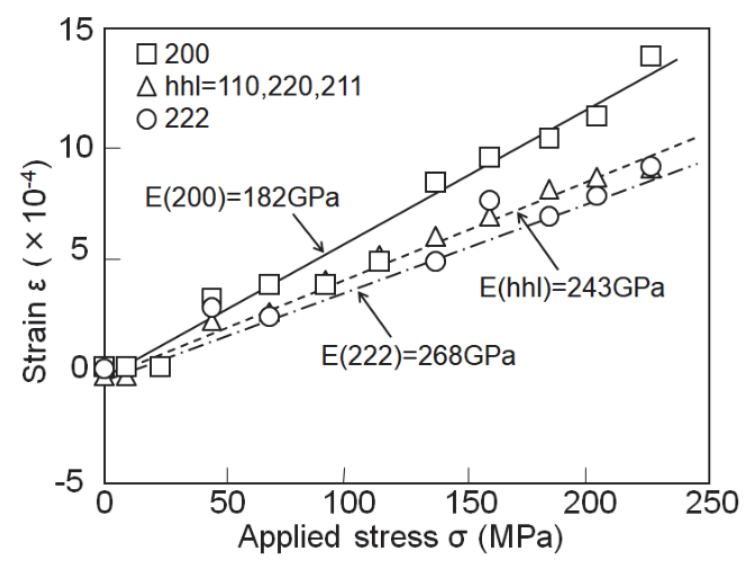

Fig. 1. Dependency of elastic constant on diffraction plane.
の回折面依存性を簡易的に評価する手法を開発し ました. Fig. 1 に炭素鋼における弾性定数（ヤン グ率）Eの回折面依存性を示します[2]. 最も柔ら かい 200 回折のヤング率が $\mathrm{E}=182 \mathrm{GPa}$ であるのに 対して, 最も硬い 222 回折のヤング率は約 $50 \%$ 高 い $\mathrm{E}=268 \mathrm{GPa}$ です.このことは弾性定数の回折面 依存性を考慮して応力を評価しないと測定精度が 悪いことを意味します。

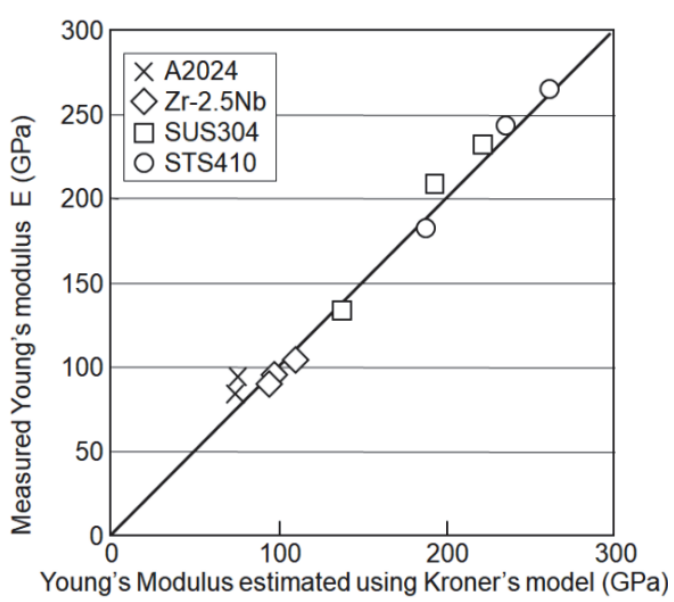

Fig. 2. Comparison of estimated Young's modulus by using Kroner's model and measured Young's modulus.

Fig. 1 のような弾性定数の回折面依存性を調べ るには数日を要します。そこで簡易的に弾性定数 を求める方法を考案しました。 それは Kroner モデ ルを使って金属単結晶の各回折面の弾性定数を求 め, それを金属単結晶のマクロな弾性定数と測定 する材料のバルクの弾性定数の比で補正するとい うものです. そのようにして求めたヤング率を横 軸に, 中性子回折により測定されたヤング率を縦 軸にとって Fig. 2 に示します[3]. 測定した材料は アルミニウム合金 (A20249) と Zr 合金 $(\mathrm{Zr}-2.5 \% \mathrm{Nb})$, オーステナイト系ステンレス鋼 (SUS304), 炭素 鋼（STS410）の 4 種です. 測定值は簡易的に求め たヤング率とほぼ一致します。この方法では引張 試験結果さえあれば良いことになり, 非常に効率 的です.

次に，炭素鋼配管の突合せ溶接継手における残 留応力を測定しました。その結果を Fig. 3 に示し ます[4]. 周方向残留応力は溶接金属で降伏応力を 超える高い引張応力で，それとバランス寸るかた ちで, 溶接金属中心から $20 \mathrm{~mm}$ 離れたところが圧 縮応力となっています. 強度上重要な軸方向応力 は内面の熱影響部で比較的高い引張応力となって います。この残留応力分布は有限要素法により解 析した結果とよく一致しており, 有限要素法によ る解析方法の妥当性を証明するものとなっていま す.

炭素鋼ソケット溶接継ぎ手における残留応力分 布を Fig. 4 に示します[5]. 測定位置は図中右上に 示したように，溶接ルート部の外面側1 からルー 卜部(4), ルート部近傍(5)からトウ部(8)の 8 カ所で す. いずれの位置でも軸方向, 周方向, 半径方向 


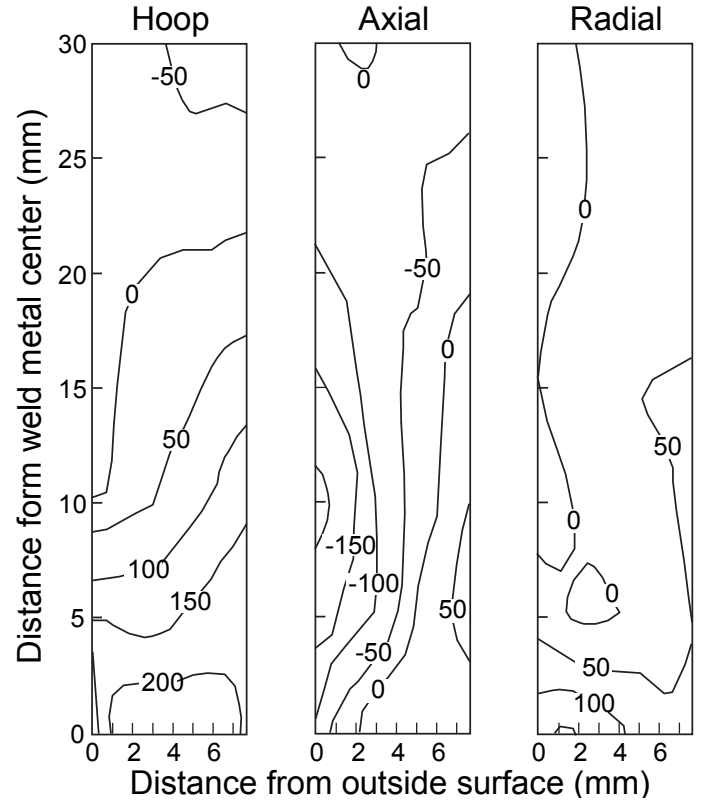

Fig. 3. Residual stress distributions in butt-welded carbon steel pipe.

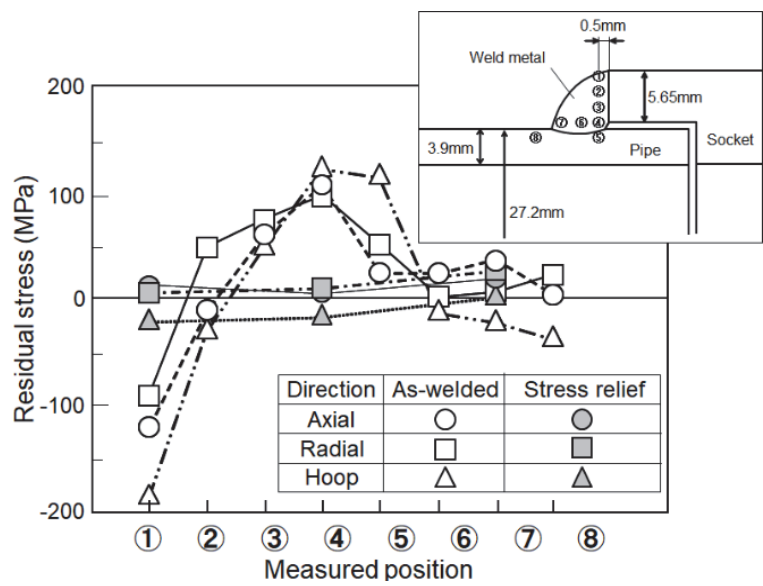

Fig. 4. Residual stress distributions in socket-welded carbon steel pipe.

応力はほぼ同じような值で静水圧的な応力分布と なっています．外面(1)では圧縮応力で，ルート部 に向かって引張応力となり, ルート部(4)では最大 $130 \mathrm{MPa}$ となっています。配管側(6)，(7)からウ 部8では応力の絶対值は 50MPa 以下と低い応力 です．有限要素法で解析した結果，(4)と(5)を除い てはよく一致しました。(1)から(4)に向かっては応 力勾配がきつく，ゲージ体積が $1 \mathrm{~mm}$ と大きいた め(4)の局部応力を精度良く測定することができま せん，有限要素法による解析ではルート部の残留 応力は約 $200 \mathrm{MPa}$ で，ソケット継ぎ手の疲労試験 結果と一致しました。中性子回折による測定と有 限要素法による解析を相補的に利用すべきである ということになります。

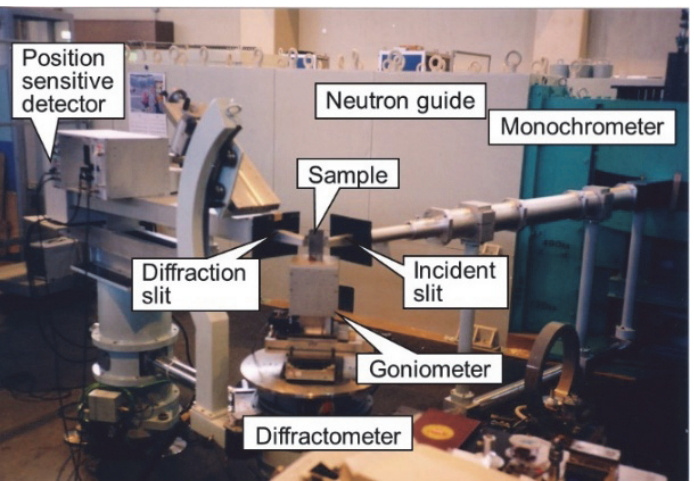

Fig. 5. Photograph of first RESA (Residual Stress Analyzer) installed in Guide Hall of JRR-3.

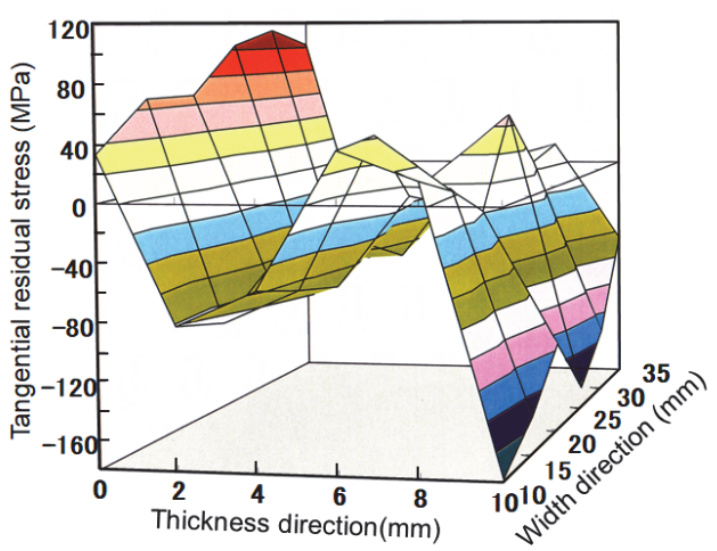

Fig. 6. Tangential residual stress distribution in bent carbon steel plate measured using by RESA.

\section{RESA の建設と利用}

Chalk River Lab.での成果を踏まえ，JRR-3 の熱 中性子ガイド T2-1 にあった回折装置を改造して RESA を 1992 年に設置しました. 当時の RESA の 写真を Fig.5 に示します[6]. 新たに製作したのは 入射側と回折側の飛行管周りとxyz3 軸ゴニオメ 一タだけで，その他の機器は従来からあったもの です。

RESAを利用して測定した結果の一例をFig.6に 示します[6]. 測定試料は板厚 $10 \mathrm{~mm}$ の炭素鋼 SM400 で, 内半径 40mm で曲げ塑性加工したもの で，その接線方向応力の分布です．多少ばらつい ていますが, 内径側から外径側に向かって引張圧縮-引張-圧縮の典型的なパターンとなっていま す。これを手始めに日立製作所と原研東海との共 同研究というかたちで様々な構造物の残留応力を 測定しました.

\section{4. 集合組織材における残留応力測定}

集合組織を有する材料の残留応力測定はX線回 折法でも頭を痛めている問題です。 中性子回折で は測定方向によって測定する回折面を変えること で対応することにしました。これはX線回折法で はできない中性子の特異なところです，方向によ って回折面を変えて測定する場合, Fig. 1 に示し たように弾性定数の回折面依存性を考慮してひず 
みを特定の回折面に合わせて補正することが必要 です。ある方向のひずみを 200 回折で測定し，基 準とする 222 回折に補正する場合には下式を用い ます。

$$
\varepsilon(222)=\varepsilon(200)-\frac{E(200)}{------}
$$

この方法をアルミニウム合金A7050で作製した 冷し嵌め材に適用しました. 冷し嵌め材の寸法は, リングが外径 $50 \mathrm{~mm}$, 内径 $25 \mathrm{~mm}$, 長さ $50 \mathrm{~mm}$ で, プラグは外径 $25.1 \mathrm{~mm}$ です。プラグを液体窒素で 冷却してリングに差し込みましたＡ７050の集合 組織を測定した結果に基づき, 軸方向は 200 回折, 周方向と半径方向は 111 回折を測定し, 111 回折 を基準としました。周方向残留応力の測定結果を Fig. 7 に示します。プラグには約 90MPa のほぼ均 一な圧縮応力が生じています。リングには内周側 で約 $250 \mathrm{MPa}$, 外周側で約 $150 \mathrm{MPa}$ の引張応力と なっています。これらの分布は有限要素法による 解析值とよく一致しました。従って，この方法が 集合組織材の残留応力測定法として有効であると 言えます。

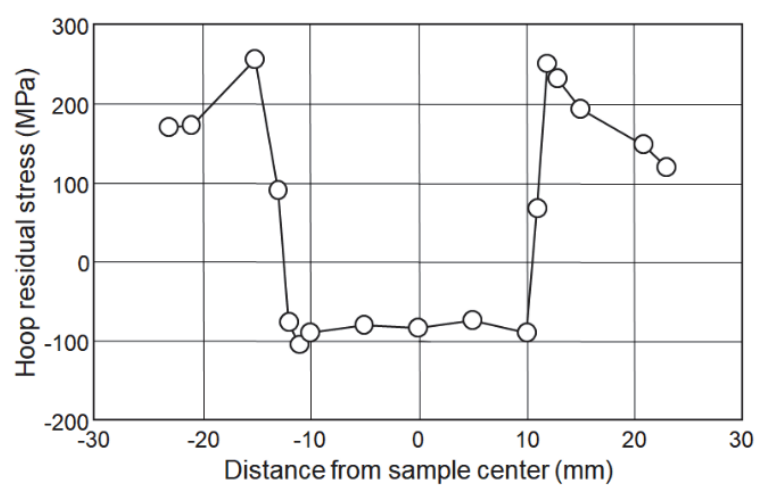

Fig. 7. Hoop residual stress distribution in shrink-fitted aluminum alloy.

\section{5. 集合組織の測定}

4.で述べたように残留応力測定においては集合 組織を把握しておくことが必要です。それとは別 に鉄鋼材料に限らず多くの材料は塑性加工を受け て集合組織を有しており，それがプレス成形性や 疲労強度などに影響を及ぼすため，集合組織は定 常的に測定されています。通常はX 線回折法で測 定しますが，全極点図を作成する場合，反射法と 透過法の両方で測定しなければならず，測定に時 間と手間がかかります。また，X 線の侵入深さは 数十 $\mu \mathrm{m}$ と小さいので表面層しか測定することが できません，一方，中性子は浸入深さが鉄鋼でも 数十 $\mathrm{mm}$ ありますのでバルク平均を測定できると いう強みがあります。茨城県の材料構造解析装置

「iMATERIA」では約 1,500 本の ${ }^{3} \mathrm{He}$ 検出器が試料 を取り囲むようにほぼ全方位に配置されているた め, 集合組織の測定に向いています。

そこで，米国 LANL LANSCE の集合組織測定装 置である「HIPPO」用に開発された MAUD という
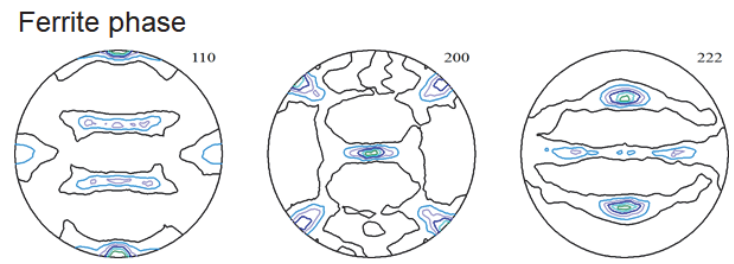

Austenite phase
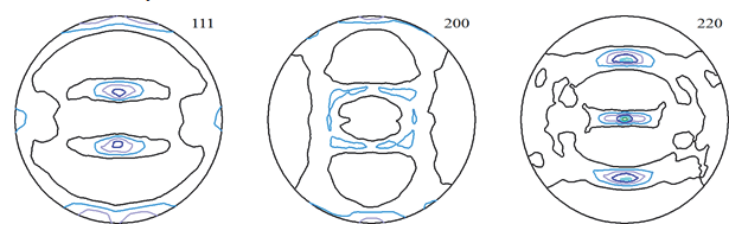

Fig. 8. Pole figures of $20 \%$ cold-rolled duplex stainless steel (SUS329J4L).

ソフトを活用した集合組織解析ソフトを開発しま した．パルス中性子源の $\mathrm{TOF}$ (飛行時間法)では多 数の回折ピークを同時に測定できることを活かし たのが MAUD です。 IMATERIA では小角バンク 検出器を除く 1,470 本の検出器を 888 領域に分け, それらをさらに 132 群に分けました。 方位として 抜けているところを補完できるのが MAUD の特 長的な機能です. 開発したソフトを使って $20 \%$ 冷 間圧延した 2 相ステンレス鋼 SUS329J4L の極点図 を Fig. 8 に示します[9]. フェライト相とオーステ ナイト相で多数の回折面を測定できますが，ここ では代表的な面だけを示しました。集合組織解析 に必要な測定時間は MLF のビーム出力が $500 \mathrm{~kW}$ であれば僅かに 2 分程度と非常に短時間です。

MLF のビーム出力が $1 \mathrm{MW}$ になれば, 鉄鋼の変態 時，あるいは，塑性変形中の集合組織の変化を in situで測定することも可能になります.

6. 中性子の産業利用

中性子の産業利用を促進するために 2008 年 5 月に中性子産業利用推進協議会を設立しました。 当初は産総研などの研究機関も含めて会員数は 57 でしたが，リーマンショックなどの影響もあり， 2017 年度は 2 研究機関と 48 企業の 50 会員で運営 しています. 協議会の主たる活動は, 中性子利用 の利便性を改善するために施設や文部科学省に対 して提言することと, 利用を普及させるための研 究会活動です。

現在，10 個の研究会では MLF の利用成果や放 射光などを利用した関連研究成果などを紹介寸る 研究会を年間 12 回程度開催するとともに, 中性子 実験技術講習会や，いわゆる「出前講座」である 企業セミナーなどを開催しています. Fig.9 に研究 会の登録者数の推移を示します. 2009 年に 250 名 余りであった登録者数が徐々に増え, 2017 年には 1,354 名となりました. 複数の研究会に登録されて いる方もおられ，延べでは 1,660 名です.

その結果, Fig. 10 に示寸ように産業利用課題数 はこの数年, 各期約 40 件で推移しています. 茨城 県ではユーザーが利用し易いように 2012A 期から 運転サイクル毎に課題申請できる随時課題受付制 


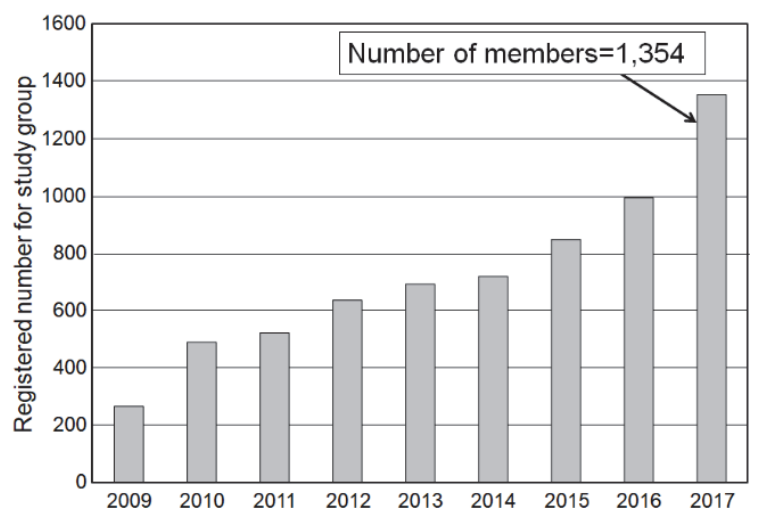

Fig. 9 Trend of number of members registered forstudying group.

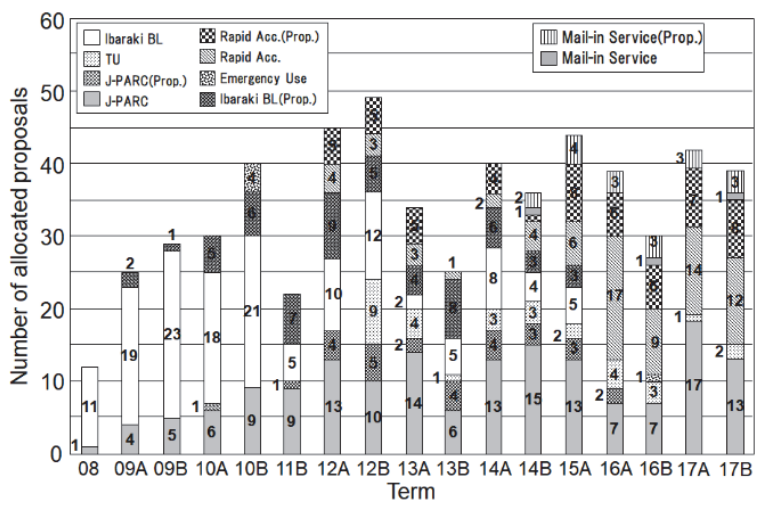

Fig.10 Trend of industrial usage in J-PARC MLF.

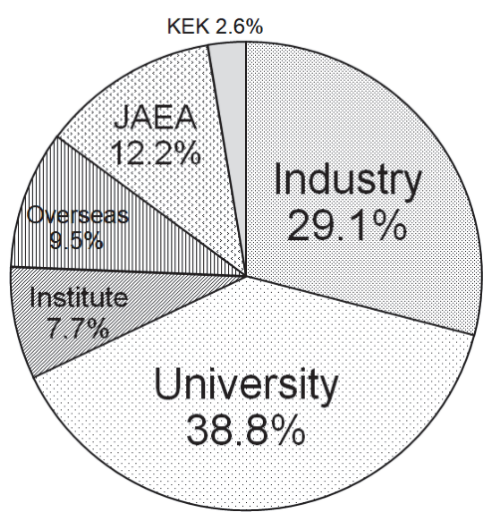

Fig. 11 Classification of proposal application to MLF.

度を開始し，さらに，2016A 期からは年間 2 回受 け付けていた定期課題募集を止め，いつでも課題 を受け付ける制度に変更しました。この場合，申 し込みから45 日以内に実験できます.また, 2014B 期からは IMATERIAにおいてメールインサービス も開始しました。これはユーザーが MLF に来る 必要はなく, 試料を茨城県が提供するホルダーに 詰めて送付すれば，装置グループが測定し，測定 終了後，試料と測定データをユーザーに送り返す というもので，ユーザーにとっては大変利用し易 い制度です。

このような施策により，MLF の産業利用は順調 であり，Fig. 11 に示すように 2008 年の供用開始 以来の課題数に占める産業界の割合は $29.1 \%$, 世界の同様な施設に比して非常に大きいという結
果になっています。また，Fig. 10 に示してありま すが，随時受付制度を開始した 2012A 期以降の IMATERIA における成果専有の利用比率は約 50\% となっています。このことは中性子が材料開発に おいて非常に有効であることを産業界が認識され ていることを示しています。

\section{7.おおりに}

1991 年に JRR-3 改造炉が運転開始するまで産業 界が中性子を利用することは皆無でした。私は 偶々必要があって利用を始め, 残留応力測定技術 の基本的なところを開発し，様々な構造物を測定 して原子力機器の信頼性向上に寄与して来ました. その結果，J-PARC MLF に茨城県が産業利用ビー ムラインを整備するに当たって，運営統括する技 監に就任することとなり, 中性子産業利用推進協 議会を設立して産業利用促進活動を推進して来ま した。最近，産業界の利用比率が以前に比して少 し低迷している感がなきにしも非ずですが，20\% 程度が妥当なところではないかと思います。これ を維持できるように引き続き利用促進活動を推進 して行きたいと思いますので，施設側のご支援， ご協力を賜りますようお願い申し上げます。

\section{謝辞}

中性子による残留応力測定技術を確立するに当 たりましては当時の Chalk River Laboratories や原 子力研究所東海研究所, 日立製作所など多くの皆 さまのご協力をいただきました．この場を借りて 心よりお礼申し上げます。

\section{参考文献}

[1] A. J. Allen, M. T. Hutchings and C. G. Windsor, Advances in Physics, 34, 445 (1985).

[2] 林眞琴，石渡雅幸，皆川宣明，舩橋達，J. H. Root，材料, 45, 1115-1120 (1995).

[3] M Hayashi, S. Ohkido, Y. Morii and N. Minakawa, Mat. Sci. Res. Int. STP-1, 418-423 (2001).

[4] 林眞琴, 石渡雅幸, 森井幸生, 皆川宣明, 材料, 45, $772-778$ (1996).

[5] 林眞琴, 石渡雅幸, 皆川宣明, 舩橋達, 材料,

44, 1464-1469 (1995).

[6] 林眞琴, 大城戸忍, 皆川宣明, 森井幸生, 材料, 47, 420-426 (1998).

[7] 林眞琴，木本寛，道下秀紀，J. H. Root，材料，46， 743-749 (1997).

[8] 大城戸忍, 林眞琴, 秋庭義明, 田中啓介, 皆川 宣明，森井幸生，材料, 54, 333-338 (2005).

[9] Y. Onuki, A. Hoshikawa, S. Sato, P. Xu, T. Ishigaki, Y. saito, H. Todoroki and M. Hayashi, J. Appl. Cryst. 49, 1579-1584 (2016). 